\title{
Simple Additive Weighting Method for The Assessment of Sharia Banking Performance
}

\author{
Metode Simple Additive Weighting untuk Penilaian Kinerja \\ Perbankan Syariah Indonesia
}

Received:

22 October 2019

Revised:

30 November 2019

Accepted:

9 December 2019

\author{
${ }^{1 *}$ Ari Suhartanto, ${ }^{2}$ Ismail Abdurrozzaq Zulkarnain, \\ ${ }^{3}$ Yoga Prisma Yuda
}

${ }^{1}$ Program Studi Informatika Universitas Doktor Nugroho Magetan

${ }^{2}$ Program Studi Informatika Universitas Muhammadiyah Ponorogo

${ }^{3}$ Program Studi Informatika Universitas PGRI Madiun

Email:1 aritapiarikaja80@gmail.com,2iizzuel@gmail.com, 3yogaprisma@unipma.ac.id

*Corresponding Author

\begin{abstract}
The interest in Sharia-based financial industry products has increased rapidly, as evidenced by a large number of conventional Bank customers migrating to Islamic Commercial Banks (BUS). With this phenomenon, it is necessary to measure BUS financial performance in Indonesia by using the analysis of the Shariah Maqashid Index (SMI) concept as control and reference for the public to choose and utilize Islamic financial products in Indonesia with an empirical study approach. The object of this study is Islamic banks in Indonesia using purposive sampling techniques with the condition that only the category of Islamic Commercial Banks. The results of this study are indicators of all mashed shariah index variables with measurements using the SAW (Simple Additive Weighting) method as decision support. Eight BUS in Indonesia have different calculation results; each Islamic bank has advantages in SMI elements. That Bank Mualamah Syariah has the highest IK1 (Performance Indicator) for two years in a row. Bank Panin Syariah has the highest IK2 in 5 consecutive years. BCAS and Bank Syariah Bukopin have the highest IK3. In general, all BUS that has implemented maqashid syariah with the category 'good' because they have an average value of 3.00 .
\end{abstract}

Keywords - simple additive weighting, maqashid sharia index, islamic commercial banks

Abstrak-Peminatan terhadap produk industri keuangan berbasis Syariah meningkat pesat dengan dibuktikan banyaknya nasabah Bank konvensional yang bermigrasi kepada Bank Umum Syariah (BUS). Dengan fenomena tersebut, maka perlu dilakukan pengukuran kinerja keuangan BUS di Indonesia dengan menggunakan analisis konsep Shariah Maqashid Index (SMI) sebagai kontrol dan referensi bagi masyarakat untuk memilih serta memanfaatkan produk-produk keuangan syariah di Indonesia dengan pendekatan studi empiris. Objek dari penelitian ini bank syariah di Indonesia dengan menggunakan teknik purposive sampling dengan syarat hanya kategori Bank Umum Syariah. Hasil dari penelitian ini indikator pada seluruh variable maqashid shariah index dengan pengukuran menggunakan metode SAW (Simple Additive Weigting) sebagai decision support. Delapan BUS di Indonesia memiliki hasil perhitungan yang berbeda-beda, masing-masing bank syariah memiliki kelebihan pada elemen-elemen SMI. Bahwa Bank Mualamah Syariah memiliki IK1 (Indikator Kinerja) tertinggi selama 2 tahun berturutturut. Bank Panin Syariah memiliki IK2 tertinggi dalam 5 tahun berturut-tutut. BCAS dan Bank Syariah Bukopin memiliki IK3 tertinggi. Penilaian secara umum, semua BUS yang telah melaksanakan maqashid syariah dengan kategori 'baik' karena memiliki nilai rata-rata 3,00.

Kata Kunci-simple additive weigting, maqashid shariah index, bank umum syariah

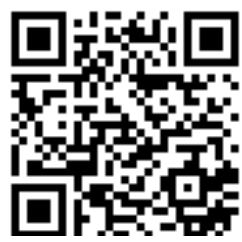




\section{INTRODUCTION}

The sharia-based financial industry is still the prima donna in this modern era. The Islamic finance and banking industry is still relatively new compared to the conventional financial and banking industry. It can be proven by the value of the Islamic banking and finance industry estimated at US 1.3 trillion dollars [1]. The sharia-based financial industry is also in great demand, not only Muslim customers but also non-Muslim customers. The sharia financial industry, in its implementation, is based on Islamic sharia principles and must follow the rules applied in sharia[2]. The Islamic finance and banking industry has gained strong trust and support, especially after the success of Islamic banking survived the 2008 economic crisis.

Indonesia is a country with a large Muslim population in the world. The existence of Muslim potential is an advantage that Indonesia has for the development of Islamic banking. The government also protects Islamic banking in Indonesia. The growth of Islamic banking in Indonesia is proof that the system implemented by Islamic banks in Indonesia can guarantee the welfare of banks and the public as customers[3]. You do this by maintaining the assets of banks and customers both in good and difficult banking situations [4].

The development of the Islamic financial industry in Indonesia has increased quite rapidly and has influenced the national banking environment. Based on statistical data of Islamic Commercial Banks (BUS), there are 7 BUSN (National Private Banks) Foreign Exchange, 9 Non-Foreign Exchange BUSN, 3 BPD, and 1 Mixed Bank (Financial Services Authority, 2017). Based on 2015-2018 data on the growth of assets, financing, and third-party funds, during the last three years, it was $0.95 \%, 10.13 \%$, and $13.02 \%$ (Hartono, 2018). Other data also found that Islamic banking assets recorded growth of 24.2\% until August 2017 [5]. The growth of Islamic banking has encouraged high competitiveness among the financial services industry[6]. Islamic banking is also able to maintain good performance so that it can compete with other banking industries, both domestic sharia banking, and sharia banking, from other countries.

Based on the results of a survey of investment behavior among consumers of Islamic banking conducted in Indonesia, especially in Java, Sumatra, and Kalimantan, there are several factors that consumers choose sharia banking. The factors of concern are sharia compliance from the bank (100\%), ease of access (53.5\%), bank credibility (27.4\%) and professionalism (14\%), (Ismail sources in BI), as illustrated in the following figure 1. 
INTENSIF, Vol.4 No.1 February 2020

ISSN: 2580-409X (Print) / 2549-6824 (Online)

DOI: https://doi.org/10.29407/intensif.v4i1.13799

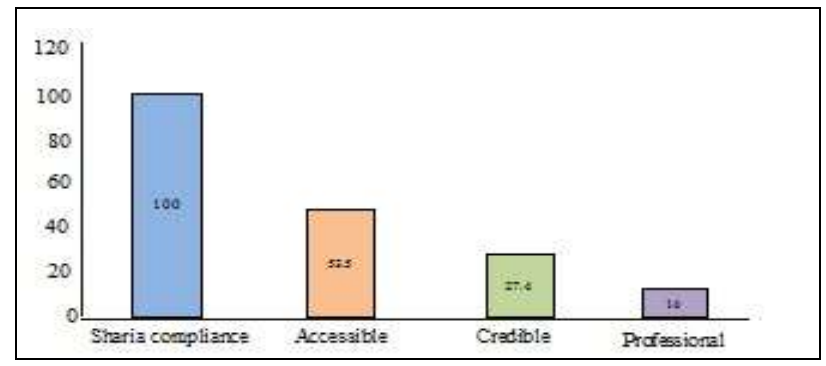

Figure 1. Selection Criteria for Islamic Banks

Taib and Abdul Razak explained that the measurement of general banking performance showed a better percentage than the measurement of conventional banking performance. The study uses the concept of maqashid shariah index according to Abdul Majid Najjar, which uses a broader and more effective concept of maqashid shariah by dividing it into four objectives and eight elements, namely Faith, Human Rights, Securing Yourself, Intelligence, Securing Heredity, Human Entity, Securing Assets and the Environment. In research on measuring the performance of Islamic banks using the maqashid shariah index, including those conducted by formulating a measurement that is useful to measure the performance of Islamic banks that are developed based on the principles of Islamic banks with the aim that there is a measurement for Islamic banks by its objectives. In previous studies regarding the measurement of sharia banking performance, the concept of maqashid shariah used was a concept proposed by Abu Zahrah[7].

With the phenomenon of the development of the Muslim population and the number of customers who have shifted to the Islamic banking system, it is necessary to measure the financial performance of BUS in Indonesia by using the analysis of the Shariah Maqashid Index (SMI) concept as a control and reference for the public to choose and utilize the products. Islamic financial products in Indonesia.

BUS performance appraisal is carried out using the Simple Additive Weighting (SAW) method and the MADM (Multiple Attribute Decision Making) approaches because the assessment technique mechanism is easily more easily understood by the general public[8], [9]. It is used because this study aims to control and reference for the public to choose and utilize Islamic financial products in Indonesia. 
INTENSIF, Vol.4 No.1 February 2020

ISSN: 2580-409X (Print) / 2549-6824 (Online)

DOI: https://doi.org/10.29407/intensif.v4i1.13799

\section{RESEARCH METHOD}

\section{A. Research Design}

The form of research carried out is quantitative research with a descriptive approach. According to the type of level of exploration, this research is comparative research that compares the evaluation of financial performance using the analysis of the shariah maqashid index (SMI) concept with an empirical study approach[10]. The unit of analysis of this study uses a group of Islamic banks (Islamic banks), namely Islamic Commercial Banks (BUS) registered at the central bank of the Indonesian state[11].

The data used in this study are secondary data, namely the annual financial report (annual report) Islamic commercial banks (BUS) in Indonesia totaling 8 (eight) BUS. The data was obtained and downloaded from the official website of the Islamic bank in question in 20132017. Data on annual financial reports in Indonesia collected from the Indonesian Financial Services Authority (OJK) in 2018. The consideration of the 2013-2017 reporting selection range was due to 2018 reporting that there were still BUSs that had not yet been published, and some BUS financial reports could not be downloaded freely.

\section{B. Data Analysis Techniques}

Sharia bank performance calculations are carried out from various aspects of the SMI using the MADM (Multiple Attribute Decision Making) approach and assessment techniques with the Simple Additive Weighting (SAW) method[12]. All indicators on all variables in the SMI are weighted and assessed by the SAW method.

The SMI variables used are aspects contained in the Tahfidz al Fard variable (Educating individuals); those are variables that use indicators to assess BUS involvement in the response program in education. The next variable is Iqamah al adl (Upholding justice) which is a variable that uses indicators to assess BUS in the process of financial transactions based on fair considerations, and Jabl al Maslahah variable (Creating Benefit) is a variable that uses indicators to assess halal -an products and restrictions on profits and losses[13]. The Variable in the following table 1 . 
INTENSIF, Vol.4 No.1 February 2020

ISSN: 2580-409X (Print) / 2549-6824 (Online)

DOI: https://doi.org/10.29407/intensif.v4i1.13799

Table 1. WEIGHTED VARIABLES IN SHARIA MAQASHID INDEX

\begin{tabular}{lclc}
\hline \hline \multicolumn{1}{c}{ Purpose } & $\begin{array}{c}\text { Average } \\
\text { weight } \\
(\mathbf{1 0 0 \% )}\end{array}$ & \multicolumn{1}{c}{ Rasio (R) } & $\begin{array}{c}\text { Average weight } \\
\mathbf{( 1 0 0 \% )}\end{array}$ \\
\hline Educate & 30 & Q1 Educational Grant & 24 \\
Individuals & & R2 Research & 27 \\
& & R3. Training & 26 \\
& Q4 Publication & 23 \\
& & Total & $\mathbf{1 0 0}$ \\
\hline Enforce Justice & 41 & Q5. Fair returns / affordable fees & 30 \\
& & R6. Distribution function & 32 \\
& & Q7 Non-interest products & 38 \\
& & Total & $\mathbf{1 0 0}$ \\
\hline Creating & & 33 \\
benefit/well-being & 29 & Q8 Profit Ratio & 30 \\
& & Q9 Personal income & 37 \\
\multicolumn{1}{c}{ T10. Investment in the real sector } \\
\hline
\end{tabular}

Based on the study of the theory[14][15][16], the attributes that will be measured in this study are eight ratios, as follows:

The first ratio is the Education Grant Ratio

$\mathrm{R} 1=\frac{\text { hibahpendidikan }}{\text { totalbiaya }}$

The second ratio, the Research Ratio

$\mathrm{R} 2=\frac{\text { biayapenelitian }}{\text { totalbiaya }}$

The third ratio, the Training Ratio

$\mathrm{R} 3=\frac{\text { biayapelatihan }}{\text { totalbiaya }}$

The fourth ratio, the Publication Ratio

$\mathrm{R} 4=\frac{\text { biayapublikasi }}{\text { totalbiaya }}$

The fifth ratio, which is the Distribution Function Ratio

$\mathrm{R} 5=\frac{\text { pembiayaan mudharabah }+ \text { musyarakah }}{}$

The sixth ratio, which is the Profitability Ratio

R6 $=\frac{\text { lababersih }}{\text { totalaset }}$

The seventh ratio, which is the Personal Income Ratio

$\mathrm{R} 7=\frac{\text { zakat }}{\text { lababersih }}$

The eighth ratio, which is the investment ratio in the real sector

R8 $=\frac{\text { investasisektorriil }}{\text { totalpenyaluran }}$

112 INTENSIF: Jurnal Ilmiah Penelitian dan Penerapan Teknologi Sistem Informasi 
Based on the formulation of the attribute formula, the following performance indicator formulations are obtained:

1. The first performance indicator is educating individuals / individual education

$$
I K 1=W_{1}^{1}\left(E_{1} x R_{1}+E_{2} x R_{2}+E_{3} x R_{3}+E_{4} x R_{4}\right.
$$

Information :

IK1: The first performance indicator

$W_{1}^{1} \quad$ : Weight for IK 1

$E_{1} \quad:$ The weight for the first ratio on IK1

$E_{2} \quad$ : The weight for the second ratio on IK1

$E_{3} \quad:$ The weight for the third ratio on IK1

$E_{4} \quad:$ The weight for the fourth ratio on IK1

$R_{1} \quad$ : The sample performance measure based on the first ratio of IK1

$R_{2} \quad$ : The sample performance measure based on the second ratio of IK1

$R_{3} \quad$ : The sample performance measure based on the third ratio of IK1

$R_{4} \quad$ : The sample performance measure based on the fourth ratio of IK1

2. The second performance indicator is to uphold justice

$$
I K 2=W_{2}^{2} x E_{5} x R_{5}
$$

Information:

IK2: The second performance indicator

$W_{2}^{2}$ : the weight for IK 2

$E_{5} \quad:$ The weights for the fifth ratio on IK2

$R_{5} \quad:$ The sample performance measure based on the fifth ratio of IK2

3. Performance indicators on the third variable are creating welfare/well-being

$$
I K 3=W_{3}^{3}\left(E_{6} x R_{6}+E_{7} x R_{7}+E_{8} x R_{8}\right)
$$

Information:

IK3: The third performance indicator

$W_{3}^{3}$ : The weight for IK3

$E_{6} \quad:$ The weight for the sixth ratio on IK3

$E_{7} \quad$ : The weight for the seventh ration on IK3

$E_{8} \quad:$ The weight for the eighth ratio on IK3

$R_{6} \quad$ : The sample performance measure based on the sixth ratio of IK3

$R_{7} \quad$ : The sample performance measure based on the seventh ratio of IK3

$R_{8} \quad$ : The sample performance measure based on the eighth ratio of IK3 
INTENSIF, Vol.4 No.1 February 2020

ISSN: 2580-409X (Print) / 2549-6824 (Online)

DOI: https://doi.org/10.29407/intensif.v4i1.13799

The final results are obtained from the sum of the three performance indicators above and are ranked according to the acquisition of the value of each Islamic commercial bank in Indonesia and Malaysia.

The final SMI score can be formulated as follows:

$$
\text { Skor } S M I=I K 1+I K 2+I K 3
$$

Information

Skor SMI is the final result / total value of SMI

IK1 is the first performance indicator

IK2 is the second performance indicator

IK3 is the third performance indicator

\section{RESULT AND DISCUSSION}

\section{A. Data Exposure}

Eight registered Indonesian Islamic banks are Muamalat Indonesia (BMI), Mandiri Syariah Bank (BSM), Mega Syariah Bank (BMS), BRI Syariah Bank (BBS), Panin Dubai Syariah Tbk Bank (BPS), BCA Syariah Bank (BCAS), Bank BNI Syariah (BNIS), and Bank Syariah Bukopin (BSB). Performance measurement of sharia commercial banks refers to three performance indicators, namely (I) the first performance indicator that is educating individuals / individual education, (II) the second performance indicator that is upholding justice, and (III) third performance indicator that is creating welfare/well-being.

The first stage in using themaqashid index is to measure its financial performance using performance ratios that are following the maqashid sharia concept[17], which is weighted with the MADM approach and measured by the data shown in the following table 2-6.

Table 2, through table 6, can be seen as the development of the financial performance of each Islamic bank in Indonesia over the past five years (2013-2017). Banking experienced relatively stable ups and downs with good value. 
INTENSIF, Vol.4 No.1 February 2020

ISSN: 2580-409X (Print) / 2549-6824 (Online)

DOI: https://doi.org/10.29407/intensif.v4i1.13799

Table 2. FinANCIAL PERFORMANCE OF BANK SyARIAH INDONESIA IN $2013(\%)$

\begin{tabular}{|c|c|c|c|c|c|c|c|c|c|c|}
\hline R1 & $\mathbf{R 2}$ & $\mathbf{R 3}$ & $\mathbf{R 4}$ & $\begin{array}{c}\text { IK1 } \\
(\mathbf{R} 1+R 2+R 3+R 4) \\
\end{array}$ & R5 & $\begin{array}{l}\text { IK2 } \\
\text { (R5) }\end{array}$ & R6 & $\mathbf{R 7}$ & $\mathbf{R 8}$ & $\begin{array}{c}\text { IK3 } \\
(\mathrm{R6}+\mathrm{R} 7+\mathrm{R8}) \\
\end{array}$ \\
\hline \multicolumn{11}{|c|}{ Bank Muamalat Indonesia (BMI) } \\
\hline \multicolumn{11}{|c|}{ Bank Syariah Mandiri (BSM) } \\
\hline \multicolumn{11}{|c|}{ Bank Mega Syariah (BMS) } \\
\hline 0,0002 & 0,0002 & 0 & 0 & 0,0004 & 0,0008 & 0,0008 & 0,0016 & 0,003 & 0,0007 & 0,0052 \\
\hline \multicolumn{11}{|c|}{ Bank BRI Syariah (BBS) } \\
\hline 0,0123 & 0 & 0,0133 & 0,0206 & 0,0462 & 0,0385 & 0,0385 & 0,0007 & 0,0015 & 0,0315 & 0,0337 \\
\hline \multicolumn{11}{|c|}{ BCA Syariah (BCAS) } \\
\hline 0,0011 & 0 & 0 & 0,0007 & 0,0018 & 0,005 & 0,005 & 0,0006 & 0,0001 & 0,4038 & 0,4045 \\
\hline \multicolumn{11}{|c|}{ BNI Syariah (BNIS) } \\
\hline 0,0024 & 0 & 0,0026 & 0,0037 & 0,0088 & 0,0213 & 0,0213 & 0,0008 & 0,0057 & 0,0175 & 0,024 \\
\hline \multicolumn{11}{|c|}{ Bank Syariah Bukopin (BSB) } \\
\hline 0,0047 & 0,0021 & 0,0051 & 0,0022 & 0,0142 & 0,0437 & 0,0437 & 0,0431 & 0 & 0,0357 & 0,0788 \\
\hline
\end{tabular}

Table 3. FinANCIAL PERFORMANCE OF BANK SyARIAH INDONESIA IN 2014 (\%)

\begin{tabular}{|c|c|c|c|c|c|c|c|c|c|c|}
\hline \multicolumn{11}{|c|}{ Bank Muamalat Indonesia (BMI) } \\
\hline 0,0006 & 0,0002 & 0,0006 & 0 & 0,0014 & 0,0648 & 0,0648 & 0,00009 & 0,0336 & 0,053 & 0,0866 \\
\hline \multicolumn{11}{|c|}{ Bank Syariah Mandiri (BSM) } \\
\hline \multicolumn{11}{|c|}{ Bank Mega Syariah (BMS) } \\
\hline 0,00003 & 0,00004 & 0 & 0 & 0,00007 & 0,001 & 0,001 & 0,0002 & 0,0213 & 0,0008 & 0,0223 \\
\hline \multicolumn{11}{|c|}{ Bank Panin Syariah (BPS) } \\
\hline 0,0014 & 0 & 0,0015 & 0,0028 & 0,0057 & 0,1151 & 0,1151 & 0,0011 & 0,003 & 0,0942 & 0,0983 \\
\hline \multicolumn{11}{|c|}{ BCA Syariah (BCAS) } \\
\hline 0,0009 & 0 & 0 & 0,0009 & 0,0018 & 0,0113 & 0,0113 & 0,0004 & 0,0002 & 0,9266 & 0,9272 \\
\hline \multicolumn{11}{|c|}{ BNI Syariah (BNIS) } \\
\hline 0,0018 & 0 & 0,002 & 0,0037 & 0,0073 & 0,0216 & 0,0216 & 0,0008 & 0,0058 & 0,0176 & 0,0242 \\
\hline \multicolumn{11}{|c|}{ Bank Syariah Bukopin (BSB) } \\
\hline
\end{tabular}

INTENSIF: Jurnal Ilmiah Penelitian dan Penerapan Teknologi Sistem Informasi 
INTENSIF, Vol.4 No.1 February 2020

ISSN: 2580-409X (Print) / 2549-6824 (Online)

DOI: https://doi.org/10.29407/intensif.v4i1.13799

Table 4. FinANCIAL PERFORMANCE OF BANK SyARIAH INDONESIA IN 2015 (\%)

\begin{tabular}{|c|c|c|c|c|c|c|c|c|c|c|}
\hline $\mathbf{R 1}$ & $\mathbf{R 2}$ & $\mathbf{R 3}$ & $\mathbf{R 4}$ & $\begin{array}{c}\text { IK1 } \\
(\mathbf{R} 1+\mathbf{R} 2+\mathbf{R} 3+\mathbf{R} 4) \\
\end{array}$ & $\mathbf{R 5}$ & $\begin{array}{l}\text { IK2 } \\
\text { (R5) } \\
\end{array}$ & R6 & $\mathbf{R 7}$ & $\mathbf{R 8}$ & $\begin{array}{c}\text { IK3 } \\
(\mathrm{R6}+\mathrm{R} 7+\mathrm{R8}) \\
\end{array}$ \\
\hline \multicolumn{11}{|c|}{ Bank Muamalat Indonesia (BMI) } \\
\hline 0,0014 & 0,0002 & 0,0015 & 0 & 0,00315 & 0,00007 & 0,00007 & 0,0001 & 0,0146 & 0,0584 & 0,0731 \\
\hline \multicolumn{11}{|c|}{ Bank Syariah Mandiri (BSM) } \\
\hline \multicolumn{11}{|c|}{ Bank Mega Syariah (BMS) } \\
\hline 0,0001 & 0,0001 & 0 & 0,0012 & 0,0015 & 0,0024 & 0,0024 & 0,005 & 0,0029 & 0,002 & 0,0098 \\
\hline \multicolumn{11}{|c|}{ Bank Panin Syariah (BPS) } \\
\hline 0,0005 & 0 & 0,0005 & 0,0014 & 0,0025 & 0,0953 & 0,0953 & 0,0016 & 0 & 0,078 & 0,0796 \\
\hline \multicolumn{11}{|c|}{ BCA Syariah (BCAS) } \\
\hline 0,0141 & 0 & 0 & 0,0076 & 0,0217 & 0,0004 & 0,0004 & 0,0005 & 0,0002 & 0,0003 & 0,001 \\
\hline \multicolumn{11}{|c|}{ BNI Syariah (BNIS) } \\
\hline 0,0004 & 0 & 0,0005 & 0,0044 & 0,0054 & 0,0076 & 0,0076 & 0,001 & 0,0049 & 0,0061 & 0,012 \\
\hline \multicolumn{11}{|c|}{ Bank Syariah Bukopin (BSB) } \\
\hline
\end{tabular}

Table 5. Financial Performance of Bank Syariah Indonesia in 2016 (\%)

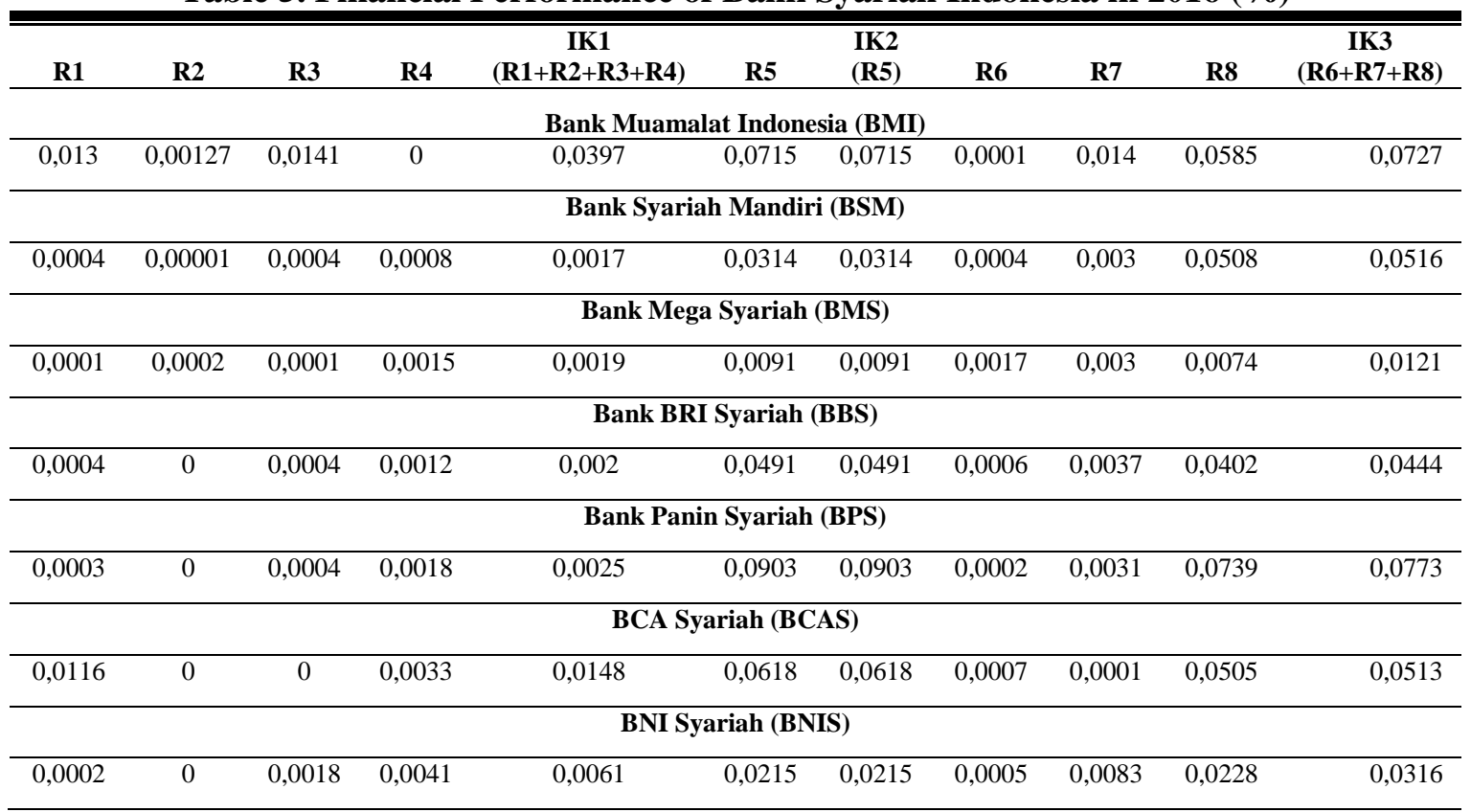

116 INTENSIF: Jurnal Ilmiah Penelitian dan Penerapan Teknologi Sistem Informasi 
INTENSIF, Vol.4 No.1 February 2020

ISSN: 2580-409X (Print) / 2549-6824 (Online)

DOI: https://doi.org/10.29407/intensif.v4i1.13799

Table 6. FinANCIAL PERFORMANCE OF SHARIA BANK INDONESIA IN 2017 (\%)

\begin{tabular}{|c|c|c|c|c|c|c|c|c|c|c|}
\hline $\mathbf{R 1}$ & $\mathbf{R 2}$ & $\mathbf{R 3}$ & $\mathbf{R 4}$ & $\begin{array}{c}\text { IK1 } \\
(\mathrm{R} 1+\mathrm{R} 2+\mathrm{R} 3+\mathrm{R} 4) \\
\end{array}$ & R5 & $\begin{array}{l}\text { IK2 } \\
\text { (R5) } \\
\end{array}$ & R6 & $\mathbf{R 7}$ & $\mathbf{R 8}$ & $\begin{array}{c}\text { IK3 } \\
(\mathrm{R6}+\mathrm{R} 7+\mathrm{R} 8) \\
\end{array}$ \\
\hline \multicolumn{11}{|c|}{ Bank Muamalat Indonesia (BMI) } \\
\hline \multicolumn{11}{|c|}{ Bank Syariah Mandiri (BSM) } \\
\hline \multicolumn{11}{|c|}{ Bank Mega Syariah (BMS) } \\
\hline 0,00002 & 0,00006 & 0,00002 & 0,00005 & 0,00014 & 0,0084 & 0,0084 & 0,001 & 0,003 & 0,0069 & 0,0109 \\
\hline \multicolumn{11}{|c|}{ Bank BRI Syariah (BBS) } \\
\hline 0,0004 & 0 & 0,0005 & 0,0012 & 0,0021 & 0,0489 & 0,0489 & 0,0003 & 0,0074 & 0,0399 & 0,0477 \\
\hline \multicolumn{11}{|c|}{ BCA Syariah (BCAS) } \\
\hline 0,0015 & 0 & 0 & 0,0007 & 0,0022 & 0,0046 & 0,0046 & 0,0008 & 0,0001 & 0,0038 & 0,0046 \\
\hline \multicolumn{11}{|c|}{ BNI Syariah (BNIS) } \\
\hline 0,0002 & 0 & 0,0002 & 0,0031 & 0,0034 & 0,0278 & 0,0278 & 0,0005 & 0,0083 & 0,0228 & 0,0316 \\
\hline \multicolumn{11}{|c|}{ Bank Syariah Bukopin (BSB) } \\
\hline 0,00006 & 0,0023 & 0,0035 & 0,0044 & 0,0103 & 0,0196 & 0,0196 & 0,2202 & 0 & 0,016 & 0,2363 \\
\hline
\end{tabular}

\section{B. Discussion}

The following is a table of Indonesia's sharia maqashid performance ratios from 2013-2017.

Table 7. MAQASHID SHARIA INDEX PERFORMANCE RATIO (\%)2013

\begin{tabular}{ccccccccc}
\hline \hline Bank & R1 & R2 & R3 & R4 & R5 & R6 & R7 & R8 \\
\hline BMI & 0,0020 & 0,0001 & 0,0021 & 0 & 0,0001 & 0,0008 & 0,0024 & 0,0537 \\
\hline BSM & 0,0008 & 0,00004 & 0,0009 & 0,0015 & 0,0280 & 0,0010 & 0,0004 & 0,0462 \\
\hline BMS & 0,0002 & 0,0002 & 0 & 0 & 0,0008 & 0,0016 & 0,0030 & 0,0007 \\
\hline BBS & 0,0123 & 0 & 0,0133 & 0,0206 & 0,0385 & 0,0007 & 0,0015 & 0,0315 \\
\hline BPS & 0,0009 & 0 & 0,0010 & 0,0013 & 0,0693 & 0,0005 & 0,0006 & 0,0567 \\
\hline BCAS & 0,0011 & 0 & 0 & 0,0007 & 0,0050 & 0,0006 & 0,0001 & 0,4038 \\
\hline BNIS & 0,0024 & 0 & 0,0026 & 0,0037 & 0,0213 & 0,0008 & 0,0057 & 0,0175 \\
\hline BSB & 0,0047 & 0,0021 & 0,0051 & 0,0022 & 0,0437 & 0,0431 & 0 & 0,0357 \\
\hline
\end{tabular}

Table 7 illustrates that in 2013 the largest education grant was given by BBS (BRI Syariah Bank) of 0.0123, followed by Bank Syariah Bukopin (BSB) and the least allocation of education grant funds was Bank Syariah Mandiri. Meanwhile, the largest research grant from Bukopin Syariah Bank was 0.0021 percent, and the smallest allocation was BRI Syariah Bank (BBS), Panin Dubai Syariah Tbk Bank (BPS), BCA Syariah Bank (BCAS), BNI Syariah Bank (BNIS) ) with a percentage allocation of 0 percent. It can also be seen that BBS (BRI Syariah 
INTENSIF, Vol.4 No.1 February 2020

ISSN: 2580-409X (Print) / 2549-6824 (Online)

DOI: https://doi.org/10.29407/intensif.v4i1.13799

Bank) in 2013 allocated the most funds according to maqashid shariah performance criteria. In contrast to BMI, BSM, and BMS, which allocate but are small in membership.

Table 8. MAQAShid Sharia Index Performance Ratio (\%)2014

\begin{tabular}{ccccccccc}
\hline \hline Bank & R1 & R2 & R3 & R4 & R5 & R6 & R7 & R8 \\
\hline BMI & 0,0006 & 0,0002 & 0,0006 & 0 & 0,0648 & 0,00009 & 0,0336 & 0,0530 \\
\hline BSM & 0,0005 & 0,00005 & 0,0005 & 0,0009 & 0,0080 & 0,00006 & 0,0055 & 0,0456 \\
\hline BMS & 0,00003 & 0,00004 & 0 & 0 & 0,0010 & 0,0010 & 0,0002 & 0,0213 \\
\hline BBS & 0,0008 & 0 & 0,0009 & 0,0019 & 0,0426 & 0,0006 & 0,0024 & 0,0348 \\
\hline BPS & 0,0014 & 0 & 0,0015 & 0,0028 & 0,1151 & 0,0011 & 0,0030 & 0,0942 \\
\hline BCAS & 0,0009 & 0 & 0 & 0,0009 & 0,0113 & 0,0004 & 0,0002 & 0,9266 \\
\hline BNIS & 0,0018 & 0 & 0,0020 & 0,0037 & 0,0216 & 0,0008 & 0,0058 & 0,0176 \\
\hline BSB & 0,0029 & 0,0012 & 0,0031 & 0,0046 & 0,1002 & 0,0158 & 0 & 0,0819
\end{tabular}

Table 8. illustrates that in 2014, of the eight ratio criteria studied, BSB (Bank Syariah Bukopin) were 5 of the eight superior criteria of other Islamic banks. BSB excels in terms of the ratio of educational grants, research grants, training grants, publication grants, and profitability ratios. Meanwhile, BCAS banks excel in the investment ratio of the real sector. In 2014, all banks relatively allocated according to the criteria in the assessment in the study, but there were four banks with zero R2 allocations, namely BBS, BPS, BCAS, BNIS.

Table 9. MAQAShid Sharia INDEX PERFormance RATIO (\%) 2015

\begin{tabular}{ccccccccc}
\hline \hline Bank & $\mathbf{R 1}$ & $\mathbf{R 2}$ & $\mathbf{R 3}$ & $\mathbf{R 4}$ & $\mathbf{R 5}$ & $\mathbf{R 6}$ & $\mathbf{R 7}$ & $\mathbf{R 8}$ \\
\hline BMI & 0,0014 & 0,0002 & 0,0015 & 0 & 0,00007 & 0,0001 & 0,0146 & 0,0584 \\
\hline BSM & 0,0009 & 0,00004 & 0,0009 & 0,0009 & 0,0065 & 0,0004 & 0,0039 & 0,0489 \\
\hline BMS & 0,0001 & 0,0001 & 0 & 0,0012 & 0,0024 & 0,0050 & 0,0029 & 0,0020 \\
\hline BBS & 0,0004 & 0 & 0,0004 & 0,0024 & 0,0501 & 0,0005 & 0,0028 & 0,0410 \\
\hline BPS & 0,0005 & 0 & 0,0005 & 0,0014 & 0,0953 & 0,0016 & 0 & 0,0780 \\
\hline BCAS & 0,0141 & 0 & 0 & 0,0076 & 0,0004 & 0,0005 & 0,0002 & 0,0003 \\
\hline BNIS & 0,0004 & 0 & 0,0005 & 0,0044 & 0,0076 & 0,0010 & 0,0049 & 0,0061 \\
\hline BSB & 0,00008 & 0,0011 & 0,0033 & 0,0033 & 0,0489 & 0,0456 & 0 & 0,0400 \\
\hline
\end{tabular}

Table 9. shows the performance ratio of the Maqashid Sharia Index in 2015. The year 2015 is the same as in 2014, where BSB (Bank Syariah Bukopin Bank) ranked first with a larger allocation compared to other Islamic banks. BSB excels at R2, R3, and R6. Meanwhile, BCAS excels in R1 and R4. R5 and R8 are superior to BPS, and R7 is superior to BMI. Just like the 
INTENSIF, Vol.4 No.1 February 2020

ISSN: 2580-409X (Print) / 2549-6824 (Online)

DOI: https://doi.org/10.29407/intensif.v4i1.13799

previous year, R2 has zero value in 4 Islamic banks. The four Islamic banks are also the same as in 2014, namely BBS, BPS, BCAS, BNIS.

Table 10. MAQASHID Sharia IndeX PERFormanCE RATIO (\%) 2016

\begin{tabular}{ccccccccc}
\hline \hline Bank & R1 & R2 & R3 & R4 & R5 & R6 & R7 & R8 \\
\hline BMI & 0,0130 & 0,00127 & 0,0141 & 0 & 0,0715 & 0,0001 & 0,0140 & 0,0585 \\
\hline BSM & 0,0004 & 0,00001 & 0,0004 & 0,0008 & 0,0314 & 0,0004 & 0,0030 & 0,0508 \\
\hline BMS & 0,0001 & 0,0002 & 0,0001 & 0,0015 & 0,0091 & 0,0017 & 0,0030 & 0,0074 \\
\hline BBS & 0,0004 & 0 & 0,0004 & 0,0012 & 0,0491 & 0,0006 & 0,0037 & 0,0402 \\
\hline BPS & 0,0003 & 0 & 0,0004 & 0,0018 & 0,0903 & 0,0002 & 0,0031 & 0,0739 \\
\hline BCAS & 0,0116 & 0 & 0 & 0,0033 & 0,0618 & 0,0007 & 0,0001 & 0,0505 \\
\hline BNIS & 0,0002 & 0 & 0,0018 & 0,0041 & 0,0215 & 0,0005 & 0,0083 & 0,0228 \\
\hline BSB & 0,00007 & 0,0019 & 0,0033 & 0,0060 & 0,0417 & 0,0454 & 0 & 0,0341
\end{tabular}

Table 10. shows the performance of the 2016 maqashid sharia index on banking in Indonesia. In 2016 BSB was still superior with three ratios that were higher than other Islamic banks. These superior ratios are R2, R4, and R6. They are followed by BMI also superior to 3 ratios after previously only one ratio. BMI's superior ratios are R1, R4, and R7. While other banks followed behind him, the effect of the magnitude of the difference between commas, but the results obtained are quite significant.

Table 11. MAQAShID SHARIA INDEX PERFORMANCE RATIO (\%)2017

\begin{tabular}{ccccccccc}
\hline \hline Bank & $\mathbf{R 1}$ & $\mathbf{R 2}$ & $\mathbf{R 3}$ & $\mathbf{R 4}$ & $\mathbf{R 5}$ & $\mathbf{R 6}$ & $\mathbf{R 7}$ & $\mathbf{R 8}$ \\
\hline BMI & 0,0050 & 0,0031 & 0,0053 & 0 & 0,00007 & 0,0001 & 0,0196 & 0,1035 \\
\hline BSM & 0,0007 & 0 & 0,0008 & 0,0010 & 0,0376 & 0,0004 & 0,0030 & 0,0606 \\
\hline BMS & 0,00002 & 0,00006 & 0,00002 & 0,00005 & 0,0084 & 0,0010 & 0,0030 & 0,0069 \\
\hline BBS & 0,0004 & 0 & 0,0005 & 0,0012 & 0,0489 & 0,0003 & 0,0074 & 0,0399 \\
\hline BPS & 0,0001 & 0 & 0,0001 & 0,0028 & 0,0780 & 0,0107 & 0 & 0,0654 \\
\hline BCAS & 0,0015 & 0 & 0 & 0,0007 & 0,0046 & 0,0008 & 0,0001 & 0,0038 \\
\hline BNIS & 0,0002 & 0 & 0,0002 & 0,0031 & 0,0278 & 0,0005 & 0,0083 & 0,0228 \\
\hline BSB & 0,00006 & 0,0023 & 0,0035 & 0,0044 & 0,0196 & 0,2202 & 0 & 0,0160 \\
\hline
\end{tabular}

Table 11. The table shows the performance ratio of the maqashid sharia index in 2017 . The results of the table can be seen that BMI is far from other Islamic banking. BMI is superior to five ratios; these ratios are R1, R2, R3, R7, and R8. BPS excels at R5. BSB in 2017 only superior in two ratios, namely R4 and R6. Other banks follow them. Just like in previous years, 
INTENSIF, Vol.4 No.1 February 2020

ISSN: 2580-409X (Print) / 2549-6824 (Online)

DOI: https://doi.org/10.29407/intensif.v4i1.13799

BBS, BPS, BCAS, BNIS allocations for research grants are worth 0. It is because, in the annual financial report, data about research grant funds are not found.

In 2013 the largest education grant was given by BBS (BRI Syariah Bank) in the amount of 0.0123, followed by Bank Syariah Bukopin (BSB), and the least allocation of education grant funds was Bank Syariah Mandiri. Meanwhile, the largest research grant from Bukopin Syariah Bank was 0.0021 percent, and the smallest allocation was BRI Syariah Bank (BBS), Panin Dubai Syariah Tbk Bank (BPS), BCA Syariah Bank (BCAS), BNI Syariah Bank (BNIS) ) with a percentage allocation of 0 percent. It can also be seen that BBS (BRI Syariah Bank) in 2013 allocated the most funds according to maqashid shariah performance criteria. In contrast to BMI, BSM, and BMS, which allocate but are small in membership. In 2014, out of the eight ratio criteria studied, BSB (Bank Syariah Bukopin) were 5 of the eight superior criteria of other Islamic banking. BSB excels in terms of the ratio of educational grants, research grants, training grants, publication grants, and profitability ratios. Meanwhile, BCAS banks excel in the investment ratio of the real sector. In 2014, all banks relatively allocated according to the criteria in the assessment in the study, but there were four banks with zero R2 allocations, namely BBS, BPS, BCAS, BNIS.

The year 2015 is still the same as in 2014, where BSB (Bank Syariah Bukopin) was ranked first with a larger allocation compared to other Islamic banks. BSB excels at R2, R3, and R6. Meanwhile, BCAS excels in R1 and R4. R5 and R8 are superior to BPS, and R7 is superior to BMI. Just like the previous year, R2 has zero value in 4 Islamic banks. The four Islamic banks are also the same as in 2014, namely BBS, BPS, BCAS, BNIS. In 2016 BSB was still superior with three ratios that were higher than other Islamic banks. These superior ratios are R2, R4, and R6. They are followed by BMI also superior to 3 ratios after previously only one ratio. BMI's superior ratios are R1, R4, and R7. While other banks followed behind him, the effect of the magnitude of the difference between commas, but the results obtained are quite significant. In 2017 it was found that BMI was superior to other Islamic banks. BMI is superior to five ratios; these ratios are R1, R2, R3, R7, and R8. BPS excels at R5. BSB in 2017 only superior in two ratios, namely R4 and R6. Other banks follow it. Just like in previous years, BBS, BPS, BCAS, BNIS allocations for research grants are worth 0 . This is because, in the annual financial report, data about research grant funds are not found.

From table 7 to table 11, it can be seen that the range of 2013 to 2017 Bank Syariah Bukopin is the most superior in allocations according to banking performance indicators based on the sharia maqashid index approach. It is followed by the bank Muamalah Indonesia, Bank Panin Syariah, BCA Syariah, BRI Syariah, and BNI Syariah. BSM and BMS in a span of five years are not superior compared to other Islamic banking. 
INTENSIF, Vol.4 No. 1 February 2020

ISSN: 2580-409X (Print) / 2549-6824 (Online)

DOI: https://doi.org/10.29407/intensif.v4i1.13799

\section{CONCLUSSION}

Eight Islamic banks in Indonesia have different calculation results, each Islamic bank has advantages in implementing the maqashid shariah index elements, and from these calculations, the results show that Bank Mualamah Syariah has the highest IK1 for two consecutive years. Participate. Bank Panin Syariah has the highest IK2 in 5 consecutive years. Sharia BCAS and Bukopin Syariah Bank have the highest IK3. All sharia banks that have implemented sharia maqashid well, namely in general Indonesia has implemented ratios in 3 indicator indicators, namely educating individuals, upholding justice, and creating benefit.

\section{REFERENCE}

[1] M. Y. Zulkepli, Islamic Finance in South East Asia \& Anti-Money Laundering Law. Malaysia, Selangor: PST Enterprise Sdn Bhd, 2013.

[2] H. E. Bedoui, "Sharī'ah-Based Ethical Performance Measurement Framework and Relevant Data to Measure Development in Light of Maqāșid al-Sharī'ah," in In Towards a Maqāșid al-Sharīah Index of Socio-Economic Development, Springer, 2019, pp. 55123.

[3] B. C. Pa, M. R. M. Nor, and S. A. Manaf, "The Needs for Official Sharia Compliance Audit Institution to Protect Customers of Islamic Banking: an Application through Hisba," Int. J. Nusant. Islam, vol. 5, no. 1, pp. 75-84, 2017.

[4] M. Fahlevi, "Pertumbuhan Perbankan Syariah di ASIA," Nuasa Oktober 2016 No 131 Th XIX, 2016.

[5] S. Rianto, "Aset Perbankan Syariah Per Agustus 2017 /tumbuh 24,2\%," Bisnis.com, 2017.

[6] A. Cakhyaneu, "PENGUKURAN KINERJA BANK UMUM SYARIAH DI INDONESIA BERDASARKAN SHARIA MAQASHID INDEX (SMI)," Amwaluna J. Ekon. dan Keuang. Syariah, vol. 2, no. 2, pp. 1-12, 2018.

[7] F. Taib and D. Abdul Razak, "The Performance Measures of Islamic Banking Based on the," IIUM Int. Account. Conf. (INTAC IV) , Putra Jaya Marroitt, vol. 1967, no. June, pp. 1-17, 2008.

[8] M. Sharma, "Multi Attribute Decision Making Techniques," Int. J. Res. Manag. Sci. Technol., vol. 1, no. 1, pp. 49-51, 2013.

[9] S. Sucipto, "Analisa Hasil Rekomendasi Pembimbing Menggunakan Multi-Attribute Dengan Metode Weighted Product," Fountain Informatics J., vol. 2, no. 1, p. 27, May 2017.

[10] M. U. Chapra, S. Khan, and A. Al Shaikh-Ali, The Islamic vision of development in the light of maqasid al-Shariah, vol. 15. Iiit, 2008.

[11] R. Haniffa and M. Hudaib, "Exploring the ethical identity of Islamic banks via communication in annual reports," J. Bus. Ethics, vol. 76, no. 1, pp. 97-116, 2007.

[12] S. Sunarti and J. Sundari, "Perbandingan Metode SAW dan Profile Matching Pada Pemilihan Rumah Tinggal," INTENSIF, vol. 2, no. 2, pp. 115-126, 2018.

[13] N. Mutia, Evi., Musfirah, "Pendekatan Maqashid Shariah Index sebagai pengukuran Kinerja Perbankan Syariah di Asia Tenggara," J. Akunt. dan Keuang. Indones., vol. 14, no. 2, pp. 181-201, 2017.

[14] T. Antonio, Sanrego., "An Analysis of Islamic Banking Performance. Maqashid Index Implemetation in Indonesia an Jordania," J. Islam. Financ., vol. 1, no. 1, pp. 12-29, 2012. 
INTENSIF, Vol.4 No.1 February 2020

ISSN: 2580-409X (Print) / 2549-6824 (Online)

DOI: https://doi.org/10.29407/intensif.v4i1.13799

[15] A. P. Widyassari, "Aplikasi Sistem Pendukung Keputusan Penilaian Kinerja Karyawan untuk Kenaikan Gaji pada PT AAA,” INTENSIF, vol. 1, no. 2, pp. 92-101, 2017.

[16] N. C. Resti, "Penerapan Metode Simple Additive Weighting (SAW) pada Sistem Pendukung Keputusan Pemilihan Lokasi untuk Cabang Baru Toko Pakan UD. Indo Multi Fish,” INTENSIF J. Ilm. Penelit. dan Penerapan Teknol. Sist. Inf., vol. 1, no. 2, pp. 102-107, 2017.

[17] M. Asutay and A. F. Harningtyas, "Developing Maqasid al-Shari'ah index to evaluate social performance of Islamic banks : a conceptual and empirical attempt.," Int. J. Islam. Econ. Financ. Stud., vol. 1, no. 1, pp. 5-64, Jul. 2015. 